\title{
Showcasing the Wealth of Service-Learning Initiatives in Asia
}

\author{
Laura L. Finley
}

Barry University, USA

\section{Recommended Citation}

Finley, L. L. (2021). Showcasing the wealth of service-learning initiatives in Asia [Review of the book Food for thought: Service-learning research in Asia, ed. by R. Shumer, C. Ma Hok Ka, \& C. Chan Wing Yee]. International Journal of Research on Service-Learning and Community Engagement, 9(1), Article 13. https://doi.org/10.37333/001c.31309 


\section{Showcasing the Wealth of Service- Learning Initiatives in Asia}

Food for Thought: Service-Learning Research in Asia, Edited by Robert Shumer, Carol Ma Hok Ka, and Constance Chan Wing Yee. Information Age Press, Charlotte, NC, USA. 2021. ISBN-13: 978-1-64802-509-9

(Paperback). 142 pp.

Reviewed by Laura L. Finley

Food for Thought: Service-Learning Research in Asia showcases the wealth of service-learning initiatives occurring in Asia, emphasizing several key themes. These include the array of disciplinary areas in which service-learning can be incorporated, the importance of relationships with the community, how to ensure servicelearning is institutionalized, and the essential role of evaluation. This book is useful for understanding how to utilize service-learning in different disciplines as well as how to institutionalize it and support educators.

\section{Muestra de la riqueza de iniciativas de aprendizaje-servicio en Asia}

Cuestiones para reflexionar: estudios sobre aprendizaje-servicio en Asia, editado por Robert Shumer, Carol Ma Hok Ka, y Constance Chan Wing Yee. Information Age Press, Charlotte, NC, USA. 2021. ISBN-13: 978-1-64802-509-9 (Libro en rústica). 142 páginas.

Reseñado por Laura L. Finley

Food for Thought: Service-Learning Research in Asia (Cuestiones para reflexionar: estudios sobre aprendizaje-servicio en Asia) muestra la riqueza de iniciativas de aprendizaje-servicio en Asia, particularmente en determinados temas clave. Dichos temas incluyen un amplio espectro de áreas disciplinares en las que puede incorporarse un componente de aprendizaje-servicio, tales como la importancia de las relaciones con la comunidad, la progresiva institucionalización del aprendizaje-servicio y el papel fundamental de la evaluación. Este libro es una guía útil para educadores a la hora de incorporar e institucionalizar el aprendizaje-servicio en diferentes disciplinas.

Palabras clave: Asia, Confucianismo, relaciones, aprendizaje-servicio
Keywords: Asia, Confucianism, relationships, service-learning

Editors' Note: English-to-Spanish translation by Maria Fernandez Cifuentes

Department of Languages, Literatures, and Cultures

University of North Florida, USA 
Service-learning is a tremendously popular method of engaged scholarship being used at colleges and universities worldwide. While much of the research published in scholarly journals focuses on the U.S. context, service-learning is a pedagogical tool that has been implemented in many institutions in Asia. This book showcases the wealth of service-learning initiatives occurring in Asia, emphasizing several key themes. These include the array of disciplinary areas in which service-learning can be incorporated, the importance of relationships with the community, how to ensure service-learning is institutionalized, and the essential role of evaluation.

The text did have some repetitive parts - for instance, many chapters opened by describing what service-learning is. Very little emphasis was placed on the distinction between service-learning and critical service-learning, although many of the projects described seem consistent with what Wasner (2016) and others have described as critical service-learning, an approach that has social justice at its core. Although data were incorporated throughout, only one chapter-Chapter Nine-included significant student voice. Further, the book would have benefited from an Appendix with additional resources.

On the whole, this is a useful book for understanding how to utilize service-learning in different disciplines as well as how to institutionalize it and support educators. A particular strength is that most of the chapters provide detailed descriptions of the service-learning projects and how they were evaluated. This focus on evaluation, and particularly including students as researchers, is critical for programs to be successful (Starratt, 2021).

Chapter Two, "The Implications of Confucianism for Service-Learning," by Carol Ma Hok Ka, provides an interesting review of how service-learning is consistent with Confucianism and moral education. The chapter emphasizes the importance of teaching students to create a new, more just society, not to simply maintain the status quo.

Chapters Three, Five, Six, Seven, Eight, and Nine illustrate the many disciplinary areas in which service-learning can be incorporated. These include arts, children's rights, ecology, disease management, news writing, and social work. Each of these chapters provides a roadmap for educators who might seek to engage in similar projects in their community. In Chapter Three, Sophia S. M. Law focuses on using service-learning in the arts to reach students, both cognitively and affectively. He Ling, Zhu Xiaoyu, and Gu Tian'an emphasize the importance of reflection in their project promoting children's human rights through service-learning. Chapter Six, by Justin R. Nayagam, Thara K. Simon, and Malini Rajagopalan Nair, describes how service-learning can be utilized to help develop eco-consciousness. Further, it makes the point that students should become acquainted not just with community service providers but also with activists working on environmental change. Christian Nindyaputra Octarino and Elizabeth Novita Wijayanti share their project on helping the community of Aililo, Rote Ndao. Their chapter provides a detailed description of the context, noting that, although farming is essential in the region, many lack knowledge about caring for livestock. Key to their service-learning project was listening to the community and then helping to fill that knowledge gap. Chapter Eight, by Siu Yan-Ho, focuses on a service-learning project for a news writing course. The project involved interviews with community members, which allowed students to better understand and connect to their own histories. In Chapter Nine, author Zuo Tao describes a service-learning initiative for social work students. Importantly, Tao emphasizes the need for reciprocal relationships between educators, students, and community partners.

Several chapters discuss how to institutionalize service-learning. This is critical for long-lasting programs and for developing consistency across campus culture. For instance, in Chapter Four, authors Clarence Ti, Joyce Tang, and Robert G. Bringle provide a case study of Singapore and reiterate the need for funding as well as for evaluation and data. Similarly, in Chapter Ten, Yinghui Cai and Xiangling Liu describe how Shantou University reformed its liberal arts curriculum around service-learning. They emphasize the importance of the relationships between teachers and students and provide information about an institutional structure that involves directors, teachers, and teaching assistants - a type of support often lacking in U.S. service-learning programs.

In sum, as the editors note in Chapter One, even though service-learning in Asia has been around for some time and has grown in scope and maturity, this book is one of the first texts to share that work. It grew out of a special issue in 2019 of the Michigan Journal of Community Service-Learning that could not 
incorporate all the contributions. Readers will welcome the richness and depth offered by all the chapters of this book.

\title{
References
}

Starratt, G. K. (2021). Community-based research as an approach to experiential learning in methodology of research: A case study. In L. L. Finley \& G. A. Bowen (Eds.), Experiential learning in higher education: Issues, ideas, and challenges for promoting peace and justice (pp. 115-132). Information Age Publishing.

Wasner, V. (2016). Critical service learning: A participatory pedagogical approach to global citizenship and international mindedness. Journal of Research in International Education, 15(3), 238-252. https://doi.org/10.1177\%2F1475240916669026.

\begin{abstract}
About the Author
Laura L. Finley, Ph.D., is a professor of sociology and criminology at Barry University.

Correspondence concerning this article should be addressed to Laura L. Finley at 1finley@barry.edu.
\end{abstract}

